\title{
Techniques for Exploitation of Gas Hydrate (Clathrates) an Untapped Resource of Methane Gas
}

Amit Arora ${ }^{1}$, Swaranjit Singh Cameotra ${ }^{2 *}$ and Chandrajit Balomajumder ${ }^{1}$

${ }^{1}$ Department of Chemical Engineering, Indian Institute of Technology, Roorkee, India

${ }^{2}$ Institute of Microbial Technology, Chandigarh, India

\begin{abstract}
Methane gas hydrates is unique source of methane gas in which gas is caught in crystalline ice like structure in permafrost regions and under the sea. The total amount of carbon present in this unique source far exceeds the conventional fossil fuels. This article briefly describes understanding of methane hydrates, their origin, occurrence, energy potential and their exploitation by techniques like depressurization, thermal stimulation, inhibitor injection, co2 sequestration, microwave technology, microwave and fluorine gas technology.
\end{abstract}

Keywords: Methane hydrate; Carbon content; Energy resource; $\mathrm{CO}_{2}$ sequestration; Microwave and fluorine gas technology

\section{Introduction}

Gas hydrates are non-stichiometric compounds formed by gases like $\mathrm{CH}_{4}, \mathrm{C}_{2} \mathrm{H}_{6}$, and $\mathrm{CO}_{2}$ etc. when they come in contact with water at lower temperature and higher pressure. There is no chemical reaction between them it is just intermingling of two compounds. In nature they are found in sea water and in permafrost regions and are seen as future fuels. Thermodynamically, their formation is favoured at lower temperature and higher pressure $[1,2]$. Such conditions are met in ocean-bottom sediments at water depths down $500 \mathrm{~m} \mathrm{[3].} \mathrm{One} \mathrm{volume}$ of gas hydrates can discharge about 160 volumes of methane and 0.8 volume of fresh water at standard temperature and pressure (STP). Gas hydrates are considered as tremendous reserve of natural methane in the earth $[4,5]$. With pressurization, gas hydrates can remain stable at temperatures up to $291 \mathrm{~K}$. Density of gas hydrae is $0.79 \mathrm{~kg} / \mathrm{L}$ [6].

The worldwide organic carbon in the gas hydrates is far more than the carbon content in total fossil fuel [7-9].

\section{Occurrence and distribution}

It is estimated that the amount of methane in the form of clathrate at the bottom of the oceans is about 6.4 trillion tons. [10]. Clathrate hydrates occur naturally on Arctic permafrost and submarine continental margins $[3,5,11,12]$. These are present in oceanic sediments along continental margins as well as in polar continental settings [1316]. Methane found within the marine sediments can be either biogenic [17] or thermogenic [18] or both of them. Clathrates are formed as per the following reaction:

$$
\mathrm{G}+\mathrm{N}_{\mathrm{H}} \mathrm{H}_{2} \mathrm{O}=\mathrm{G} \cdot \mathrm{N}_{\mathrm{H}} \mathrm{H}_{2} \mathrm{O}
$$

$\mathrm{G}$ is the guest molecule which is methane occurs most abundantly in natural hydrates [19-21]. NH is the hydration number i.e., average number of water molecules per guest molecules in a unit cell of crystalline gas hydrate compound.

The gas hydrates synthesized in the lab is as shown in Figure 1.

\section{Energy potential}

There is uncertainty on the amount of methane caught in gas hydrates. The idea given by the studies in pre-1990 of the amount of methane caught in global gas hydrates deposits of the amount of methane trapped in global gas hydrate deposits were in the range from $\sim 10^{17} \mathrm{ft}^{3}$ or $10^{5}$ trillion cubic feet [TCF] [22] to $10^{8}$ TCF [23]. With the same period, Kvenvolden (1988) [24,25], Gornitz et al. [26], and Harvey et al. (1995) [27] has also gave similar ideas. In the mid 1990 numerical modelling, evaluation have given the total volume of gas sequestered in gas hydrates from 1.4 to $1.7 \times 10^{5} \mathrm{TCF}[28,29]$ to $4.2 \times 10^{6}$ TCF [30] with some intermediate estimates [31] In the most recent review on the concerned, subject Boswell et al. (2011) [32] estimate of $10^{5}$ TCF of methane caught in gas hydrates (gas-in-place or GIP), USA department of energy has said that if only very very less amount of methane stored in hydrates can be exploited. It is almost more than the current supply of natural gas in the country $[33,34]$. It was mentioned that the energy potential of methane hydrates is greater than that of the other unconventional [35]. Gas hydrates will be a source of attention till their development potential is assessed [36]. Methane hydrates are

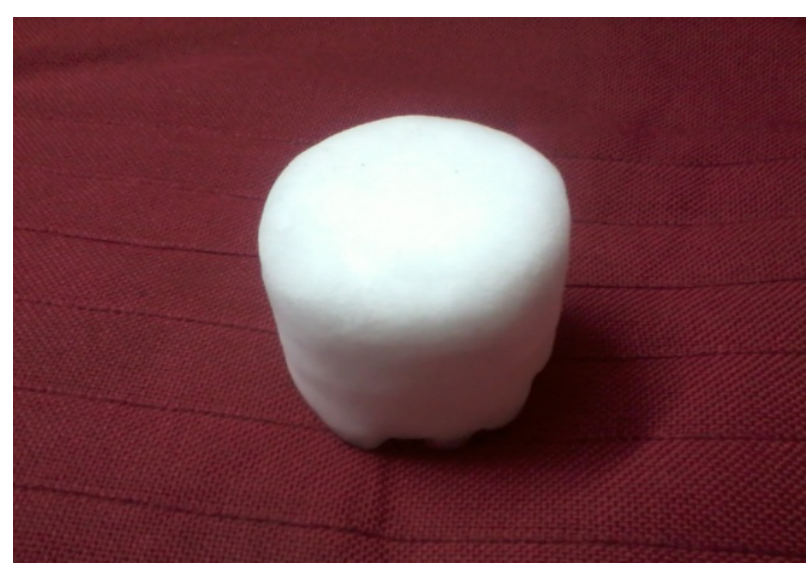

Figure 1: Gas hydrate synthesized in lab by our group.

*Corresponding author: Swaranjit Singh Cameotra, Institute of Microbial Technology, Chandigarh, India, Tel: +91-9041036750; E-mail: ssc@imtech.res.in

Received January 20, 2015; Accepted March 17, 2015; Published March 24, 2015

Citation: Arora A, Cameotra SS, Balomajumder C (2015) Techniques for Exploitation of Gas Hydrate (Clathrates) an Untapped Resource of Methane Gas. J Microb Biochem Technol 7: 108-111. doi:10.4172/1948-5948.1000190

Copyright: ( $\odot 2015$ Arora A, et al. This is an open-access article distributed under the terms of the Creative Commons Attribution License, which permits unrestricted use, distribution, and reproduction in any medium, provided the original author and source are credited 


\begin{tabular}{|l|c|c|c|}
\hline Parameter & $\begin{array}{c}\text { Thermal Stimulation } \\
\text { Method }\end{array}$ & $\begin{array}{c}\text { Gas Extraction method } \\
\text { Depressurization }\end{array}$ & 166000 \\
\hline Investment in millions of Rs. & 254200 & 125500 & 157500 \\
\hline Annual cost in millions of Rs. & 160000 & 1557.43 & 100000 \\
\hline Total production(million $\left.\mathrm{m}^{3} / \mathrm{year}\right)$ & 1274.26 & 4025.9 & 1557.43 \\
\hline Production cost (Rs./million $\mathrm{m}^{3}$ ) & 6356.6 & 2532.3 & 3213.6 \\
\hline Break-even wellhead price (Rs./million $\mathrm{m}^{3}$ ) & 7945.8 & 3972.9 \\
\hline
\end{tabular}

Table 1: Economics of various dissociation processes [38]

assumed upcoming source of hydrocarbon energy and will be a future fuel $[37,38]$.

\section{Current Techniques of Extraction of Gas from Natural Gas Hydrates}

The natural gas from gas hydrate can be produced via depressurization, chemical inhibitor injection and thermal stimulation which have been discussed in literature their economics is as shown in Table 1

\section{Novel Techniques of Extraction of Gas from Natural Gas Hydrates}

The conventional techniques have various disadvantages as discussed above, so there is a motivation of inventing a technology which is more efficient, more economical and more green. Various techniques are being studied at lab scale like gas exchange $\left(\mathrm{CO}_{2}\right.$ sequestration), microwave technology, Fluorine gas and microwave technology but these need to be investigated in detail before going for commercial productions. These are explained as per the following details:

\section{Gas exchange ( $\mathrm{CO}_{2}$ sequestration)}

This technique exploits the greater solubility of $\mathrm{CO}_{2}$ in water to displace natural gas and hence it achieves the two positive results in a single process i.e., extraction of natural gas from gas hydrates and removal of $\mathrm{CO}_{2}$ from atmosphere. The gas exchange between $\mathrm{CO}_{2}$ and $\mathrm{CH}_{4}$ was first proven in lab by Ohgaki et al. [39], Ohgaki et al. [40]. The experiment observed there is a preference for $\mathrm{CO}_{2}$ clathrate over. $\mathrm{CH}_{4}$ in hydrate phase. Not only equilibrium consideration but the heat of $\mathrm{CO}_{2}$ hydrate formation $(-57.9 \mathrm{~kJ} / \mathrm{mol})$ is more than the heat of dissociation of $\mathrm{CH}_{4}(54.5 \mathrm{~kJ} / \mathrm{mol})$, which is favoring for the natural exchange of $\mathrm{CO}_{2}$ with $\mathrm{CH}_{4}$ hydrate, because the above change process is exothermic [41]. Multiphase exchange of $\mathrm{CO}_{2}$ for $\mathrm{CH}_{4}$ was given by Hirohama et al. [42]. The author claimed much more rapid $\mathrm{CH}_{4}$ recovery using gaseous $\mathrm{N}_{2}$. A mixture of $\mathrm{CO}_{2}$ and $\mathrm{N}_{2}$ can also be tried for exchange with $\mathrm{CH}_{4}$ from gas hydrate. The technology of gas exchange is shown as per the following (Figure 2).

\section{Microwave technology}

In conventional heat transfer processes, energy is carried to the material via convection, conduction and radiation because of thermal gradients. But, in microwave energy is passed directly to materials through their molecular interaction with the electromagnetic field. Microwave heating is the change of electromagnetic energy to thermal energy. Microwaves can pass through materials and deposit energy; heat can be created throughout the volume of the material. So, it can decrease processing times and prove to be energy efficient [43]. Petroleum industry has used microwave irradiation recently [44-46].

The exploitation of natural gas hydrate (NGH) for the recovery

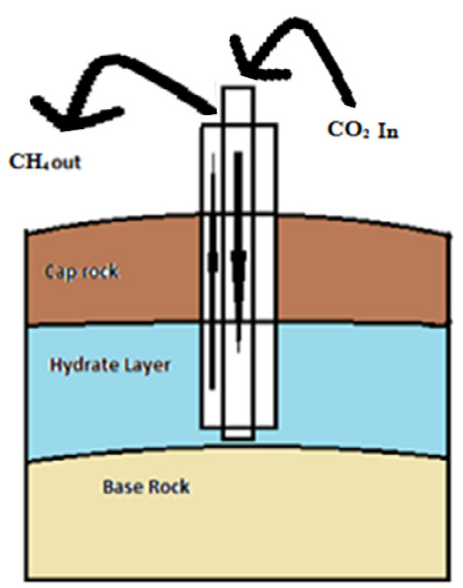

Figure 2: $\mathrm{CO}_{2}$ sequestration method.

of gas since possible via heating and microwaves are also gaining attention as heating media in oil and gas industry. The decomposition of hydrates with microwaves were studied by Rogers [47]. While this experiment, the power of microwave was increased gradually. The results showed that microwave heating was very prominent method for hydrate dissociation. Other groups reported experimental studies on the dissociation of propane hydrate by microwave are Fatykhov et al. [48]. The kinetics of methane hydrate crystallization using molecular dynamics simulation in the presence of microwave is reported by English et al. [49]. It was concluded that NGH will dissociate when the intensity was more than a certain value, because the movement of the molecules in the system was increased by microwave.

Advantages of gas hydrate decomposition using Microwave:

Based on the literature review on use of microwave in gas hydrate following advantages are found:

Firstly water is heated by microwave which heats hydrates and dissociates the hydrates and this phenomenon of bulk heating leads to high decomposition efficiency.

Decomposition water created while the hydrate decomposition enhances hydrate decomposition, and the decomposition water and microwave have a synergic effect on the hydrate decomposition.

Gas hydrate can be decomposed dissociated soon with microwave. The more the power is, the greater the decomposition rate is. However, there is a heat efficiency issue generated from the more system temperature.

The microwave heating results into very soon decomposition of gas hydrate compared to other methods.

The studies revealed that the difference of dielectric properties 
within the components may result in temperature difference in the system while the gas hydrates decompose. The hydrate decomposition with microwave is a joint effect of numerous mechanisms.

With the same pressure, microwave can enhance the phase equilibrium temperature.

While the microwave radiation, there is a linear relationship between temperature and time. The rate of hydrate dissociation increases with increasing microwave power.

The energy ratio of microwave heating is more than that of water bath heating, but it is lower than the theoretical value of thermal stimulation production.

Selective heating is possible with microwave. Microwave also increases permeability and porosity.

Keeping into view the above advantages a novel technology like fluorine gas and microwave technology have been proposed explained as below:

\section{Flourine gas and microwave technology}

In this method a micro strip antenna with huge power gain and is inexpensive is used with wire line, the tool is placed in well bore and a frequency of $2450 \mathrm{MHz}$ is generated which melts the gas hydrate into water and methyl radical which destabilises the thermodynamic condition and after this fluorine is injected which results into halogenations which is strongly exothermic and releases $-431 \mathrm{KJ} / \mathrm{mol}$ and methyl fluoride is soluble in water and the solubility is $166 \mathrm{cc}$ per $100 \mathrm{ml}$ of water. This pressurised gas can be obtained via tubing from production well. After this by applying Wurtz reaction, electrolysis and cracking, methane can be recovered. This method enjoys the advantage of green technology because methyl fluoride is eco-friendly. No extra heat is introduced into the reservoir. The diagram of this technology is shown Figure 3.

\section{Environmental Impact of the Use of this Energy Source}

The latest research going on in the field of exploitation of this resource of energy is through $\mathrm{CO}_{2}$ sequestration, hence this energy source can be obtained by dumping $\mathrm{CO}_{2}$ in sea which will help in reducing global warming. The only threat which is involved is the controlled release of methane from the gas hydrates while $\mathrm{CO}_{2}$ Sequestration for which lot of research is going on. Even if it is

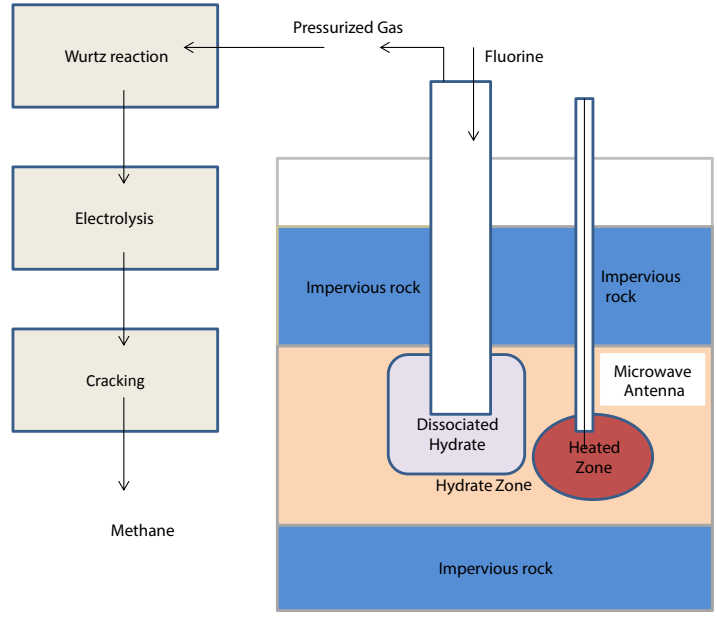

Figure 3: Gas extraction using the microwave technique [50]

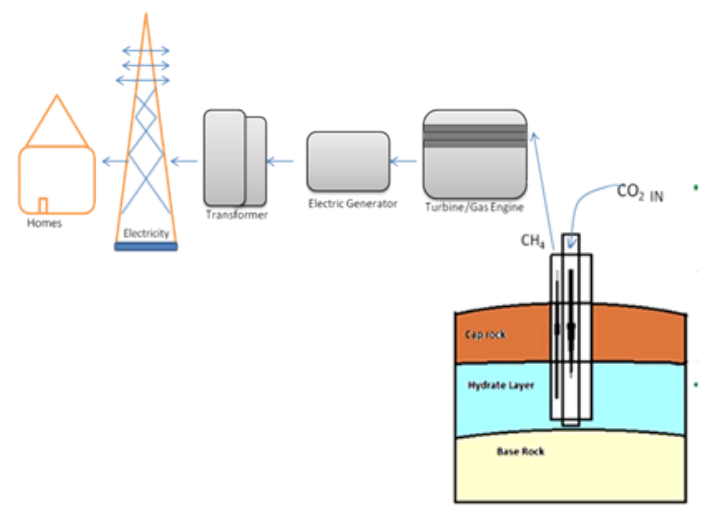

Figure 4: Gas exchange.

dissociated in uncontrolled manner much of methane from dissociated gas hydrate will never reach the atmosphere, rather it may be converted to $\mathrm{CO}_{2}$ and sequestered by biosphere and hydrosphere before reaching the hydrates. Moreover While combustion of methane 25\% lesser $\mathrm{CO}_{2}$ is released in comparison to when the same mass of coal is combusted and moreover methane don't emit the nitrogen and sulphur oxides which makes it more environment friendly.

\section{Energy Efficiency Benefit Cost of using Methane Hydrates}

Almost $\$ 500$ Billion of US economy is used for fuel. The consumption of energy is expected to increase which will generate the extra demand for the crude oil which is already getting consumed at a faster rate. The amount of methane hydrate is enormous and if very less of methane hydrate can be exploited it can meet the energy demands for centuries. Gas hydrates will be new kind of source of natural gas. The global gas hydrate reserves are almost 100 times more than the natural gas reserves in the world at present [50]. If we are able to exploit only $10 \%$ of the gas hydrates reserves it can help in meeting the energy requirements for 600 years [51]

\section{Use of Methane Hydrates in Electricity Generation and Direct Use}

There is shift going on from coal based power generation to gas based power generation because of enormous benefits, so in the current context gas hydrates can be directly used for the power generation using $\mathrm{CO}_{2}$ Sequestration and in situ combustion also. The schematic line proposed diagram for the production of electricity from methane hydrates is as shown in Figure 4.

\section{Conclusions}

An enormous amount of methane is available in the gas hydrates. Even a small percentage of which could meet the energy requirements of the world for centuries. Long term production test are going on in USA and Japan to make the production viable. Many techniques have been discussed in this paper. However, there is a strong need to prepare a suitable viable economic and green commercial technology for exploiting this untapped energy resource.

\section{References}

1. Sloan ED (1990) Clathrate Hydrate of Natural Gases. Marcel Dekker. New York.

2. Sloan EDJ, Koh C (2007) Clathrate hydrates of natural gases (3rdedn) CRC Press 
Citation: Arora A, Cameotra SS, Balomajumder C (2015) Techniques for Exploitation of Gas Hydrate (Clathrates) an Untapped Resource of Methane Gas. J Microb Biochem Technol 7: 108-111. doi:10.4172/1948-5948.1000190

3. Kvenvolden KA (1993) Gas hydrates-Geological perspective and global change. Reviews of Geophysics 31: 173-187.

4. Dobryin VM, Korotavej Yu P, Plyuschev DV (1981) Gas hydrates- a possible energy resource. In: Meyer RF, Joslon JC (eds.) Long term energy resources. Pitman publishing, Boston, pp. 727-729.

5. Sloan ED (1998) Clathrate Hydrates of Natural Gases (2ndedn.) Marce Dekker, New York, pp. 705

6. Suess E, Bohrmann G, Rickert D, Kuhs WF, Torres ME, et al. (2001) Properties and fabric or near-surface methane hydrates at Hydrate Ridge, Cassadia Margin. Proceedings of the fourth international conference on gas hydrates, Yokohama.

7. Satoh M, Maekawa T, Okuda Y (1996) Estimation of amount of methane and resources of gas hydrates in the world and around Japan. J Geol Soc Japan 102: 959-971.

8. Kvenvolden KA (1998) A primer on the geological occurrence of gas hydrate. Geol Soc Lond Spec Publ 137:9-30

9. Collett TS (2002) Energy resource potential of natural gas hydrates. AAPG Bul 86: 1971-1992.

10. Buffett B, Archer D (2004) Global inventory of methane clathrate: sensitivity to changes in the deep ocean. Earth Planet Sci Lett 227:185-199.

11. Kvenvolden KA (2000) Natural gas hydrate: introduction and history of discovery In: Max MD (ed.) Natural gas hydrate in oceanic and permafrost environments. Kluwer, Norwell, pp. 9-16.

12. Durham WB, Kirby SH, Stern LA, Zhang W (2003) The strength and rheology of methane clathrate hydrate. J Geophys Res 108: 2182

13. Paul Charles K, Dillon, William $P$ (2000) Natural gas hydrates; occurrence, distribution and detection. American Geophysical Union. Washington DC United States. Geophysical Monograph 124: 315.

14. Hester K, Brewer P G (2009) Clathrate Hydrates in Nature. Annual Reviews of Marine Science 1: 303-327.

15. Kvenvolden KA, Rogers BW (2005) Gaia's breath-global methane exhalations. Mar Pet Geol 22: 579-90.

16. Council of Canadian Academies (2008) Energy from gas hydrates: assessing the opportunities and challenges for Canada.

17. Singh A, Singh BD ( 1999) Methane Gas: An unconventional energy resource. Current Science 76: 1533-1545.

18. Vogt PR, Crane K, Sundvor E, Hjelstuen BO, Gardner J, et al. (1999) Ground - Truthing 11 to $12 \mathrm{kHz}$ side-scan sonar images in the Norwegian - Greenland Sea: Part II: Probable diapirs on the Bear Island fan slide valley margins and the Vering Plateau. Geo-Marine Letters 19: 11-130.

19. Mahajan D, Taylor CE, Mansoori GA (2007) An introduction to natural gas hydrate/clathrate: the major organic carbon reserve of the Earth. J Pet Sci Eng 56: 1-8.

20. Mazzini A, Ivanov MK, Parnell J, Stadnitskaia A, Cronin BT, et al.(2004) Methane-related authigenic carbonates from the Black Sea: geochemical characterization and relation to seeping fluids. Mar Geol 212:153-181.

21. Popescu I, De Batist M, Lericolais G, Nouzé H, Poort J, et al. (2006) Multiple bottom simulating reflections in the Black Sea: potential proxies of past climate conditions. Mar Geol 227: 163-166.

22. Mciver RD (1981) Gas hydrates. In: Meyer RF, Olson JC (eds.) Long-term energy resources. Pitman, Boston, pp. 713-726.

23. Trofimuk AA, Cherskii NV, Tsaryov VP (1977) The role of continental glaciation and hydrate formation on petroleum occurrence. In: Meyer RF (ed.) The future supply of nature-made petroleum and gas. Pergamon Press, New York, pp. 919-926.

24. Kvenvolden KA (1998b) Estimates of the methane content of worldwide gashydrate deposits, methane hydrates: resources in the near future. Paper presented at JNOC-TRC, Japan, 20-22.

25. Kvenvolden KA (1988c) Methane hydrate - a major reservoir of carbon in the shallow geosphere. Chem Geol 71: 41-51.

26. Gornitz V, Fung I (1994) Potential distribution of methane hydrates in the world's oceans. Glob Biogeochem Cycles 8: 335-347.
27. Harvey LDD, Huang ZJ (1995) Evaluation of the potential impact of methane clathrate destabilization on future global warming. Journal of Geophysical Research 100 (D2): 2905-2926.

28. Milkov AV (2004) Global estimates of hydrate-bound gas in marine sediments: how much is really out there. Earth Sci Rev 66: 183-197.

29. Buffett B, Archer D (2004) Global inventory of methane clathrate: sensitivity to changes in the deep ocean. Earth Planet Sci Let 227: 185-199.

30. Klauda JB, Sandler SI (2003) Phase Behavior of Clathrate Hydrates: A Mode for Single and Multiple Gas Component Hydrates. Chem Eng Sci 58: 27-41.

31. Wood W, Jung W (2008) Modeling the extent of Earth's marine methane hydrate cryosphere. Proceedings of the 6th International Conference on Gas Hydrates ICGH, July 6-10, Vancouver, British Columbia, Canada.

32. Boswell R, Collett TS (2011) Current perspectives on gas hydrate resources. Energy and Environmental Science 4: 1206-1215.

33. Holder GD, Malone RD, Lawson WF (1987) Effects of Gas Composition and Geothermal Properties on the Thickness and Depth of Natural-Gas-Hydrate Zones. Journal of Petroleum Technology 39: m147-1152.

34. Haq BU, Boulder CO (1998) Gas hydrates; greenhouse nightmare? Energy panacea or pipe dream? Geological Society of America (GSA) 8: 1-6.

35. MacDonald GJ (1990a) Role of methane clathrates in past and future climates Clim Change 16: 247-281

36. Grauls D (2001) Gas hydrates: importance and applications in petroleum exploration. Marine and Petroleum Geology 18: 519-523.

37. Kvenvolden KA, McMenamin MA (1980) Hydrates of natural gas: a review of their geologic occurrence. US Geol Surv Circ 825: 1-11.

38. Pierce BS, Collett TS (2002) Energy resource potential of natural gas hydrates. In: Proceedings of the 5th Conference Exposition on Petroleum Geophysics, Hyderabad, India, pp. 899-903.

39. Ohgaki K, Takano K, Moritoki M (2004) Exploitation of $\mathrm{CH}_{4}$ Hydrates under the Nankai Trough in Combination with $\mathrm{CO}_{2}$ Storage. Kagaku Kogaku Ronbunshu 20: $121-123$.

40. Ohgaki K, Takano K, Sangawa H, Matsubara T, Nakano S (1996) Methane Exploitation by Carbon Dioxide from Gas Hydrates-Phase Equilibria for $\mathrm{CO}_{2}$ $\mathrm{CH}_{4}$ Mixed Hydrate System. J Chem Eng Japan 29: 478-483.

41. Smith DH, Seshadri K, Wilder JW Assessing the Thermodynamic Feasibility of the Conversion of Methane Hydrate into Carbon Dioxide Hydrate in Porous Media. First National Conference on Carbon Sequestration, National Energy Technology Laboratory.

42. Hirohama S, Shimoyama Y, Wakabayashi A, Tatsuta S, Nishida N (1996) Conversion of $\mathrm{CH}_{4}$-Hydrate to $\mathrm{CO}_{2}$. Hydrate in Liquid $\mathrm{CO}_{2}$. J Chem Eng Japan 29: 1014-1020.

43. Thostenson ET, Chou TW (1999) Microwave processing: fundamentals and application. Composites: Part A. 30: 55-1071.

44. Xia LX, Lu SW, Cao GY (2003) Demulsification of emulsions exploited by enhanced oil recovery system. Sep Sci Technol 38: 4079-94

45. Rajakovic V, Skala D (2006) Separation of water-in-oil emulsions by freeze/ thaw method and microwave radiation. Sep Purif Technol 49: 192-6.

46. Bjorndalen N, Islam MR (2004) The effect of microwave and ultrasonic irradiation on crude oil during production with a horizontal well. J Petrol Sci Eng 43: 139-50.

47. Rogers RE (1999) Decomposition with microwaves. Natural gas hydrates storage project final report.

48. Fatykhov MA, Bagautdinov NY (2005) Experimental investigations of decomposition of gas hydrate in a pipe under the impact of a microwave electromagnetic field. High Temperature 43: 614-9.

49. English NJ, MacElroy JMD (2004) Theoretical studies of the kinetics of methane hydrate crystallization in external electromagnetic fields. J Chem Phys 120 : 10247-10255.

50. Garg R, Ogra K, Choudhary A, Menezes, R (2008) Chemical Recovery of Gas Hydrates using fluorine gas and microwave technology. Conference on Society of Petroleum Engineers, CIPC/SPE Gas Technology Symposium Joint Conference Calgary, Alberta, Canada, 16-19 June.

51. BP (2014) BP Statistical Review of World Energy. 